Logos Universality Mentality Education Novelty, Section:

Political Sciences and European Studies

ISSN: 2284 - 5992 (print), ISSN: 2284 - 5992 (electronic)

Covered in: CEEOL, Index Copernicus, Ideas RePeC, EconPapers, Socionet

\title{
THE REPUBLIC OF MOLDOVA AND \\ UKRAINE IN THE CONTEXT OF RUSSIAN FEDERATION'S SPHERE OF INFLUENCE
}

\author{
Svetlana CEBOTARI \\ Carolina BUDURINA-GOREACII
}

DOI:

http://dx.doi.org/10.18662/lumenpses.2015.0301.02

Logos Universality Mentality Education Novelty, Section: Political Sciences and European Studies, 2015, Volume III, Issue 1, pp: 13-33

Published by:

Lumen Publishing House

On behalf of:

Lumen Research Center in Social and Humanistic Sciences 


\title{
The Republic of Moldova and Ukraine in the Context of Russian Federation's Sphere of Influence
}

\author{
Svetlana CEBOTARI ${ }^{1}$ \\ Carolina BUDURINA-GOREACII ${ }^{2}$
}

\begin{abstract}
The fission of the late URSS and the appearance on its territory of 15 new independent states generated for Russia absolutely a new geopolitical and geostrategic situation. Russia was "pushed on the bottom of Eurasia" an event perceived as something inadmissible for the country which during the centuries has played a major role not only in the international policy but also at the European level. At the same time, pretending to be qualified as a great power, Russia aspires after the retrieval of the past state, that of Super power. To reach its purpose, Russia used different pressures with Republic of Moldova and Ukraine concerning the relations of political, economic and military aspects.

So, the present article examines the dimension of strategies of hard and soft power of Russian Federation to maintain Republic of Moldova and Ukraine in its sphere of influence.
\end{abstract}

Keywords: strategy, geopolitical interest, geostrategic interests, the interest sphere, Transnistrian conflict, Superpower, hard power, soft power.

\footnotetext{
${ }^{1}$ Ph.D. in political sciences, Associate professor, Faculty of International Relations, Political and Administrative Sciences, Moldova State University, svetlana.cebotari@mail.ru, +373 068977695 .

2 MA, lecturer, Faculty of International Relations, Political and Administrative Sciences, Department of Applied Foreign Languages, Moldova State University, carolina.budurin@gmail.com, +37306095490.
}

Cebotari, S., Budurina-Goreacii, C. (2015). The Republic of Moldova and Ukraine in the Context of Russian Federation's Sphere of Influence. Logos Universality Mentality Education Novelty, Section: Political Sciences and European Studies, III(1), 13-33. Doi: http://dx.doi.org/10.18662/lumenpses.2015.0301.02 


\section{Introduction}

In a period of about 25 years from the end of the Cold War and the collapse of the former USSR, Russian Federation has been trying to restore its great power status. Since the second half of the 2000s, Russia has relaunched a policy to restore its power status. Russia's main goal is to have influence in ex-Soviet countries, including Moldova and Ukraine, areas where Russian Federation shows geostrategic interests. In order to achieve geopolitical and geostrategic interests Russian Federation uses a wide range of strategies: from hard to soft power use, which according to experts are the main elements of the war of the new generation - the hybrid war.

\section{The dimension of Russian Federation strategies to maintain its sphere of influence in Moldova and Ukraine}

If we look in terms of time, the use of hard power strategy by Russian Federation was found even in the early of 90s. The Transnistrian conflict has only a geopolitical aspect. The issue of Russian military presence appeared in political and legal terms where according to the Decree no. 234 on 14 November 1992 the Soviet Army military units (arms, ammunition, vehicles, military equipment, military bases and other property) were deployed in the country and declared property of the Republic of Moldova. On March 18 1992, the Decree no. 73 issued by President M. Snegur stipulated that "in order to create the basis for the establishment of the Republic of Moldova Armed Forces", the ex-Soviet military units deployed in Moldova were put under the jurisdiction of Moldova and given to the Ministry of Defence "with all equipment, weapons, buildings and other assets on the balance of military units".

Ignoring the Decrees of the former Moldovan President M. Snegur, on 1 April 1992, B. Yeltsin, Russian President, has issued the Decree no. 220 "On passing under Russian jurisdiction the military units of the Armed Forces of the former USSR temporarily placed in the Republic of Moldova". Under this Decree, "the 14th Guards Army, formations, military units and institutions of the Armed Forces of the former USSR, deployed on the territory of the Republic of Moldova and which are not part of its armed forces, were transferred under Russian jurisdiction and the subordination of the Supreme Command of the Joint Armed Forces of the CIS. Moving the troops under Russian Federation jurisdiction is explained by the following 
reasons: to maintain a stable administration and to ensure the functioning of troops, to not admit the involvement of troops in interethnic conflicts; to protect socially the soldiers and their families.

Although the Decree on 1 April 1992 was an illegal and unfriendly act from Russian Federation, the Moldovan government didn't contest it. This is probably explained by the fact that the Decree was issued in a much tensioned period of relations between Moldova and Russia, one of its purposes referring to not allow the troops involvement in the conflict. There are a number of reasons to consider the Decree issued by President B. Yeltsin as an illegal one. It is unanimously accepted that in a state there are national laws and rules of international law which this state has accepted, adhering to certain conventions, international treaties. The President's Yeltsin Decree, however, in spite of this universally accepted rule, has extended over a territory that was not part of Russian Federation, over some organizations and a property that did not belong to Russia. So, considering the above, the Decree on 1 April 1992 cannot be considered legal, and also the military equipment, weapons, ammunition and other wealth of ex-Soviet troops deployed on Moldovan territory on the date of issuance of this Decree belonged to Moldova and Russia has acquired a property that didn't belong to it (Gribincea, 1999: pp.124-125).

Separatists from Transnistria are Moscow assets and draw the attention of NATO forces in Europe. Another risk factor reported by analysts refers to elections in the Moldova's autonomous region of Gagauzia, where the separatist movement is getting stronger. In this context, NATO and the EU must maintain economic sanctions applied to Russia, otherwise there is the possibility for Moscow to try to destabilize Moldova, as Britain's prime minister, D. Cameron mentioned (***, Adevarul.ro). "There are Russian troops in Transnistria to prevent Moldova to move to the West", the NATO commander has recalled (Scurt istoric al evoluției relațiilor Republicii Moldova cu Rusia). For Kremlin, the area between Bugeac and Odessa is of strategic importance, ensuring the corridor between Transnistrian separatists, those from Crimea, Donetsk and Lugansk. Activation of the frozen conflict in Transnistria is the biggest threat over Moldova and the entire region. According to information provided by Transnistria, in August 2014 there were officially 402 Russian troops in Transnistria in the formally peacekeeping mission. They actively cooperate with the forces under Tiraspol administration - 492 employees. 
Transnistria offered help to the separatist republics of eastern Ukraine not only through human beings, but also the high level specialists former employees of the Security Offices. In July, for example, Mr. V. Antiufeiev, the former state minister of security in Transnistria, was appointed as the deputy prime minister for state security in the separatist republic Donetsk, being transferred there on a direct order from Moscow as a result of malfunction of local authorities. Beside this, Russian Federation used Transnistrian citizens as combatants during the provocative actions produced in Odessa in May 2014. In June it was announced the creation of the youth organization „Zvezda” (the Star) in Transnistria, its main purpose focusing on preparing the youth for military service and their participation in military actions. In fact, it refers to the creation of some paramilitary units, which have proven their efficiency during military actions in eastern Ukraine. It should be noted that this organization cooperates actively with the Russian Institute of Strategic Research. Meanwhile, Transnistria continues to do things that could be considered preparatory for military actions. For example, in August 2014 the KGB Special Forces from the separatist area have conducted parachuting exercises that weren't planned previously. On August 20, 2014 there was held a special training for reservists designed for civil officials. V. Putin who became the president of Russian Federation in 2000, through the undertaken actions demonstrated that he wanted to reconstruct as much as possible the former Soviet Union territory. An action in this sense was to reintegrate Ukraine in the area of Russian Federation's influence. Thus, through its policies, Russian President tries to rebuild Russian influence in the geopolitical space of the USSR, to restore Russia's great power status and to promote this new recreated Russian civilizational identity on the international agenda. To this end, V. Putin uses all political, economic, diplomatic, military and imagological tools to achieve his "imperialist" goal, according to many experts. Thus, Russian Federation has restarted to promote more actively its interests worldwide, which has resulted in direct confrontations with influential powers of the international community. Thus, under the economic regeneration of Russian Federation, political and economic elites have begun to support the expansive policy of President V. Putin. Russian Federation has proved that it doesn't hesitate to use military force when it considers that its interests are at stake (***, 2015, Analiza CESI: p.130). To understand the way of Russian thinking, we need to look at two events. First is the Orange Revolution in Ukraine. From the standpoint of the United States and the Europeans, the 
Orange Revolution represented a triumph of democracy and Western influence. From Moscow's point of view, the Orange Revolution was a disturbance of internal affairs of Ukraine that was financed by CIA and which was designed to draw Ukraine into NATO and add it to Russia's encirclement. US Presidents - G.W. Bush and B. Clinton had promised Russian Federation that NATO would not expand into the former Soviet empire. That promise had already been broken in 1998 by NATO's expansion to Poland, Hungary and Czech Republic, and in 2004, in the three Baltic States, which belonged to Soviet Union. Discussions on including Ukraine in NATO were a fundamental threat to Russia's national security. This would have made Russia become indefensible and would have caused even a destabilization of Russian Federation.

The annexation of Crimea to Russia proved to be the most dangerous geopolitical event of the post-Cold War period and even after the Cuban missile crisis. The annexation could cause two types of actions, both harmful for the stability of Europe on the long term. The first option was to regain Russia's influence in the region and the right to redraw borders and to exercise veto power over governments of neighbouring states. The second option was the Ukrainian government to fight back, helped by Westerners, which could lead to a Yugoslav-style civil war. An "anti-terrorism" operation was launched by officials in Kiev in April 2014 in order to quell the proRussian armed insurrection in Donetsk and Lugansk regions. P. Poroshenko became the president of Ukraine and even in his Investiture Speech he declared that he will reject any "compromise" with Russia regarding the country's European orientation and the Crimea belonging to Ukraine. Although it seemed the situation was moving towards better, the cease of gas supplies to Ukraine by Gazprom proved the contrary. Moreover, after 10 days of armistice offered unilaterally by Ukrainian forces, authorities have declared the anti-terrorism fighting. NATO officials stated that they "are concerned with the fact that Russian troops at the border with Ukraine may represent a threat to the southeast of Ukraine". Moreover, after concentrating heavily the Russian troops on the border with Ukraine, V. Putin declared that "Russia hopes from now on equal relations with Western states, after having defended geopolitical interests in the Ukrainian crisis, and it will continue to defend the interests Russian ethnic groups in other countries". This statement of Russian president just confirms the plan to regain Russian influence in former Soviet states (***, 2015, Analiza CESI: p.128).

Cebotari, S., Budurina-Goreacii, C. (2015). The Republic of Moldova and Ukraine in the Context of Russian Federation's Sphere of Influence. Logos Universality Mentality Education Novelty, Section: Political Sciences and European Studies, III(1), 13-33. Doi: http://dx.doi.org/10.18662/lumenpses.2015.0301.02 
Russian Federation supports its intervention by presenting as argument the right to self-determination of Crimean population, similar to the case in Kosovo. Russia's recent campaign in Crimea was an impressive demonstration of strategic communication, one that, although it has many aspects similar to those in South Ossetia and Abkhazia, however, presented a number of specific traits as a result of operational reflection of the new Russian military directives desired to be implemented by 2020. The success of this campaign is the fact that in just three weeks, the Ukrainian military spirit was affected in so that all 190 units surrendered. Rather to rely on massive deployment of tanks and artillery, Russia used in this campaign forces of assault whose value was less than 10000 men - already stationed in Crimea, mostly marines, supported by several battalions of troops and commandos of special forces - Spetsnaz. In addition, the heaviest used vehicles referred to armoured personnel carriers BTR-80. These have countered about 16000 Ukrainian soldiers (***, 2015, Analiza CESI, p.133). Russia will not give Ukraine to the West and, if to do so; in no case it will leave Crimea and Sevastopol. Ukraine, according to its current territorial format, has no chance to join the EU or NATO, regardless of enthusiasm of speech of the new leaders from Kiev or even the will of the majority population in the west.

Also, another hard power instrument refers to the economic one that is very often used by Russian Federation in order to achieve its interests in the East European area. Oil and gas are Russia's most precious resources. V. Putin has used the energy dependence of Ukraine, Moldova and many European countries as a political tool of negotiation and blackmail. This happened in 2006, as in the winter of 2008-2009, as a result of misunderstandings where Russian Federation has stopped supplying gas to Ukraine for a period. The decision to take over Crimea was the result of several factors; one of them was that, in September 2013, Ukraine has signed the concession agreements for exploration and exploitation of gas deposits in the Black Sea, a step that would reduce the energy dependency on Russia. The agreements referred to "the exploitation of gas from the north-western Black Sea, a gas field estimated at nearly 10.8 billion cubic meters". Meanwhile, Russia has started an economic project of building a Eurasian economic union that includes as many of the former satellites of the USSR. Currently, the union attracted only Russia, Belarus and Kazakhstan. Bringing Ukraine into the Eurasian economic circle would have followed the ambitious plan of President V. Putin to restore Russian Federation as the

Cebotari, S., Budurina-Goreacii, C. (2015). The Republic of Moldova and Ukraine in the Context of Russian Federation's Sphere of Influence. Logos Universality Mentality Education Novelty, Section: Political Sciences and European Studies, III(1), 13-33. Doi: http://dx.doi.org/10.18662/lumenpses.2015.0301.02 
main actor of the global international arena. By signing the economic agreement of cooperation with the former President V. Yanukovych it seemed that Ukraine gave up its way into the EU. But V. Yanukovych was chased from power by the people and in the immediate future it is impossible for Russia to regain its influence in Ukraine as a whole, a fact that led to the invasion in Crimea, "in order to control at least a part of the country" (Baltag, 2010).

Economy is one of the driving forces of international relations and one of the main Russian Federation's assets. Rich in raw material, Russian Federation is an energetic power, with more than $18 \%$ of world reserves of gas, which is placed on the second position in the world and $5 \%$ of world oil reserves). In post-Soviet area the Russia's strategy is articulated on a project that aims at maintaining under the influence ex-Soviet republics that are in conflict (Moldova, in 2014 Ukraine, which has an Euro-Atlantic orientation) (Sieg, 2014). Analysing the energy aspect, it is to mention that the Gazprom's tough behaviour towards Ukraine and Moldova has a (geo) political and (geo) economic aspect, with the pro-Western orientation of the official authorities in Kiev and Chisinau. In terms of official statements and actions, Moscow intimates expressly that it would never accept the panWestern military structures to get closer in the immediate vicinity. Thus, the energy blackmail against Kiev and Chisinau is only a tool of pressure to ensure the Russian national security. On the one hand it is a signal to the West in terms of its influence eastward expansion (particularly political and military), which undermines Russia's national interests in the region. On the other hand, these actions are permanent reminders for Ukraine and Moldova, prompting them to review their own position vis-à-vis its accession to the Western structures. In this context, we mention the Moscow's intention to influence the internal political situation in these two countries, which is unstable because of the differences in positions and disagreements between different political forces (Nastase, 2015).

The tough policy of Gazprom, which had a negative impact on Kiev and Brussels, draws explicitly political and geopolitical connotations, based on the national interests of Russia in its immediate proximity. Officially Moscow repeatedly intimates that it will never accept the approximation of west military structures in the immediate vicinity and prevent such circumstances that are able to act in the most drastic way. Thus, the energy blackmail against Kiev is just the first step to ensure the national security and to alert the West to discard its policies that reach national/ state interest of 
Russian Federation, where Ukraine is a vital one. At the same time, it is a warning to Ukraine, causing it to review its position vis-à-vis its accession to the Western structures. It is obvious that Kremlin also aims at certain commercial and energy interests. In this context, it would be nice to draw attention to an aspect. The official cause of the gas conflict between Ukraine and Russian Federation didn't refer to Kiev's non-payment for the gas debt. But if not to forget that Transnistria debt is much higher, then we see once again that the real reason of the conflict between Kiev and Moscow didn't have a financial aspect, but geopolitical and geo-energy ones (Baltag, 2010).

In terms of energy, Moldova is totally dependent on Russian gas, which is used by the second as another tool to impose its will in certain territories (Tinguy, 2015). In fact, for a quarter of a century Russian Federation participates in writing the destiny of Moldova: Moldova, as an independent country since 1991, has become almost entirely dependent on Russian fuel supplies. Half of the state company "Moldovagaz" belongs to Russian giant "Gazprom". Whenever Moldova tried to escape the influence of Russia, Moscow makes pressures by using the delivery of gas and, more often, embargoes. In September 2013, when it became possible a partnership with the EU, Russia stopped imports of Moldovan wine and divine, citing the reason for poor quality. Sanctions have become tougher in the summer of 2014, when Russian Federation didn't import fruit from Moldova, after being signed the Association Agreement with the European Union (Tinguy, 2015).

Currently the gas industry in Moldova is directed from the outside, being 100\% dependent on one export market - Russian Federation, by one supplier - S.A.R. "Gazprom". Furthermore, all gas industry in the country is in the hands of Russian monopolist, Moldova losing control of this strategically important industry.

So far the issue of price for the gas imported from the Russian Federation remains a sensitive one for Moldova following the revision of Gazprom relations with former Soviet republics, these changes being felt by countries with pro-Western orientation. In this respect, we draw attention to the fact that Gazprom didn't sign any long-term agreements which establish a fixed price for energy resources with many former Soviet states. Thus, we believe that in the near future they will not be signed, for some political and strategic reasons. This leads us to believe that Moscow will continue to use the energy weapon to influence the political course of underdeveloped

Cebotari, S., Budurina-Goreacii, C. (2015). The Republic of Moldova and Ukraine in the Context of Russian Federation's Sphere of Influence. Logos Universality Mentality Education Novelty, Section: Political Sciences and European Studies, III(1), 13-33. Doi: http://dx.doi.org/10.18662/lumenpses.2015.0301.02 
countries and $100 \%$ dependent on energy from it, as is the case of Moldova (Gribincea, 1999: pp.124-125).

Another factor that has political repercussions refers to the debt of Moldova to Russian Federation for imported natural gas resources. Currently S.A. "Moldovagaz" has a debt of about 2.4 billion USD for gas imported from Russia. Of this amount, approx. 2 billion USD are debts of Transnistria. Tiraspol's debt belongs to the company "Tiraspoltransgaz" LLC, which manages the gas network in Transnistria, but is not a part to the purchase and sale contract of natural gas between "Gazprom" and "Moldovagaz. Therefore, Gazprom has the legal right to ask us to repay all debts, both of Chisinau and Tiraspol". We want to emphasize that debts are the main channel of economic and / or political pressures. Thus, Tiraspol's debt accumulated during the last 18 years are "on the shoulders" of Chisinau, which even doesn't control the territory.

Thus, Tiraspol administration negotiates the terms of transmission to Gazprom its share in Moldova-gaz. Tiraspol wants also to get the opportunity to conclude direct contracts with Gazprom on gas supplies in the transnistrean region. It is also negotiated a rescheduling of payment of huge debts that Tiraspol has to Gazprom. It finds us hard to believe that such an arrangement would suit Moscow, as Russian Federation does not need an independent Transnistria. Until 2008 the separatist authorities were paying for Russian gas a price which was 4-5 times lower than in Moldova. But starting with 2008, Gazprom, "unexpectedly" realized that it has no longer possibility to supply gas at preferential prices to Transnistria, but at the same prices they give to Republic of Moldova as well. So it is not difficult to conclude that Tiraspol's debts will increase in "geometric progression", which now automatically become Chisinau's debts. In these conditions we can expect at "surprises" which could determine Moscow to hold all the levers in the Moldovan energy sector. Moreover, it is not difficult to figure out where the policy in the energy sector will be made in Moldova. In short, we can say with certainty that we will depend directly on the Russian giant. We note that the low prices from Transnistria were to raise debts for gas supplied by "Gazprom". It is certainly a factor in the shade and little noticed, but we believe that debts (about 2.4 billion USD) qualified as of the Republic of Moldova, will lead "Gazprom" to claim later from us. As long as Transnistria is not an independent subject, the interpretation of international law by Russian Federation may be affected negatively on Moldova to pay debts for the gas imported (***, 2008,

Cebotari, S., Budurina-Goreacii, C. (2015). The Republic of Moldova and Ukraine in the Context of Russian Federation's Sphere of Influence. Logos Universality Mentality Education Novelty, Section: Political Sciences and European Studies, III(1), 13-33. Doi: http://dx.doi.org/10.18662/lumenpses.2015.0301.02 
Culiuc.com). In this context we can say that Moscow uses "Gazprom" as a foreign policy tool, trying to cover gaps faced by Moldova, in particular, the energy risks.

Monetary and financial destabilization of Moldova through its banking system, taken over and controlled by the Russian Federation is also a hard power strategy of reducing the confidence of population in European development vector. The point of the fifth column in this particular case was made by the Moldovan Government, on the one hand and the National Bank, on the other hand. Lei (Moldovan currency) instability, soaring prices, deepening and expanding poverty, fostering desperation and disbelief in tomorrow, boosting the exodus of young people and qualified labour force are all coordinated actions of an extremely dangerous hybrid war that are against Moldova (Saharneanu, 2015) .

Another Russia's hard power tool to achieve geopolitical interests through economic weapon refers to imposing embargoes on different products. Since March 2006, Russia has introduced different sanctions against exporters from Republic of Moldova, Ukraine. If we analyse the causes of these sanctions, then each of them has the same reasondisobedience or intention to get out of Russian Federation's influential sphere (Goncearov, 2009). Russian Federation is one of economic and political partners of Moldova. In the last 24 years Moldovan-Russian relations have been marked by uncertainty and incoherence. Moscow has reached its peak in 2005-2006. Moldovan wine and agricultural products were boycotted and political negotiations in the $5+2$ format were run on a deadline up to 2011. After refusing to sign the "Kozak Memorandum", relations between Moldova and Russian Federation have become tensioned, both countries bringing mutual recriminations to fail signing the document. Moreover, after 2004, when V. Voronin understood that he couldn't find any support from Moscow that began to directly support Smirnov, the Moldova's foreign policy course has changed, focusing, at least formally, toward the European Union (EU). The highlight of this period was consumed by introducing the new regime at the Moldovan-Ukrainian border in March 2006, a measure that was interpreted in Tiraspol and Moscow as the economic blockade. In response, Russia imposed an embargo on Moldovan wine exports which seriously affected the Moldovan economy. This led President V. Voronin to become more receptive to Russian proposals (Tinguy, 2015).

Cebotari, S., Budurina-Goreacii, C. (2015). The Republic of Moldova and Ukraine in the Context of Russian Federation's Sphere of Influence. Logos Universality Mentality Education Novelty, Section: Political Sciences and European Studies, III(1), 13-33. Doi: http://dx.doi.org/10.18662/lumenpses.2015.0301.02 
Both from official and media level, Russia has undertaken an attitude stating the action as an "economic blockade", accusing Moldova of creating a "humanitarian catastrophe" in Transnistria, stopping the Moldovan wine imports, which is one of the major branches of the Moldovan economy. In this context, the rhetoric of Moldova to the Russian Federation changed. The ex -foreign Minister A. Stratan and the President V. Voronin stated that Transnistria is a region occupied by Russia. During this period, on 22 July 2005 it was unanimously adopted the "Law on the status of autonomy of the districts from the left bank of Dniester River (Transnistria)". Also together with Ukraine it has been managed to bring the European Union Border Assistance Mission to Moldova and Ukraine (EUBAM) at the MoldovanUkrainian border. However, with no external support and having economic problems due to Russian sanctions, the government from Chisinau was forced to be more receptive to Russian proposals. So, in the so-called package proposed by Moldova to Russia there are found a number of provisions, such as providing a broad autonomy to Transnistria, recognition of properties from that place, the special status for Russian language, permanent neutrality, and Russian military presence in the reunified Moldova. So far, however, neither V. Putin nor D. Medvedev did officially respond to this proposal, but from the leadership's actions in Moscow it comes to think that these proposals are not enough, Russia desiring more provisions in particular on neutrality calling for signing an international document that would ensure all this. In general, it seems that Russian Federation would abandon the status quo only if its change would make the Russian influence to the increase over Moldova (Tinguy, 2015).

Russian ban on import of Moldovan and Georgian wines began in late March 2006 and created a major diplomatic conflict between the Republic of Moldova on the one hand and Russia on the other. The wine trade with Russia covered at that moment $80-90 \%$ of total wine exports between the two countries. The Russian Sanitary Chief Inspector G. Onishchenko said that in Georgian and Moldovan wines there were found heavy metals and pesticides and that they have forged alcoholic products labelled as wine (***, 2009, Asociatia pentru Politica Externa). Russian Agency for Consumer Protection claimed that it has examined 21 varieties of Georgian wine sold in Moscow and concluded that $85.7 \%$ did not meet sanitary requirements. Pesticides were found in $60 \%$ of samples from Moldova. However, the Moldovan authorities have argued that there are evidence provided by even Russians and dozens of other countries around

Cebotari, S., Budurina-Goreacii, C. (2015). The Republic of Moldova and Ukraine in the Context of Russian Federation's Sphere of Influence. Logos Universality Mentality Education Novelty, Section: Political Sciences and European Studies, III(1), 13-33. Doi: http://dx.doi.org/10.18662/lumenpses.2015.0301.02 
the world that they import Moldovan wine without any problems. Moldova stated that the ban is actually an economic blackmail. The ban on wine imports was put in a time of worsening diplomatic relations between the countries as well as the divergence of positions between Russia and Moldova on the Transnistria future. A year earlier, Russian Duma called for a ban on imports of Moldovan wine as Moldova was considered to promote the antiRussian policies to Moldovan wine imposed by Russia in March 2006 (***, 2008, Culiuc.com).

In this context, there can be mentioned also the embargoes in autumn 2013 imposed to Moldova for wine and meat products, as well as the embargo in 2014 for fruit. Also, in 2013 Russian Federation imposed an embargo to chocolates of Ukrainian origin. With a careful analysis of the conditions under which these sanctions were imposed by Russia, it is obvious that all of them were of political nature. At the Eastern Partnership Summit in Vilnius, held on 28-29 November 2013, in which the ex-Soviet states Moldova, Ukraine and Georgia were expected to sign the Association Agreement with the EU, rushes the post-Soviet geopolitical space. Moldova receives a strong increasing support from the EU. Moldova has become the biggest beneficiary of EU financial support per capita. If we examine the EU's geopolitical interests in Moldova then there are not convincing the statements that the EU, in Moldova, is guided by geopolitical reasons. Obviously, in Eastern Europe there was a competition between the vector of European and Euro-Asian integration. Conflicts such as those in Ukraine or Moldova affect the European security and the instability in Eastern Europe that can generate threats to other EU countries, such as the organized crime. In this sense, European integration is also for the EU as an instrument to overcome the chronic instability in Eastern Europe. In the case of Moldova, the European integration does not work only as a way to ensure stability of the country through participation in a larger Union. Rather, here the European integration is an external provider for reforms and internal conditions that Moldova needs to improve its development. For half a century of united Europe, the European Union has acquired experience where the implementation of the EU's fundamental values human rights, rule of law, good governance, democracy and market economy with equal opportunities are the best guarantees to ensure prosperity and stability (Sieg, 2014). Thus, Russia has used all available instruments to obstruct the European way undertaken by these countries. Russian pressures have increased once with improving relations of these

Cebotari, S., Budurina-Goreacii, C. (2015). The Republic of Moldova and Ukraine in the Context of Russian Federation's Sphere of Influence. Logos Universality Mentality Education Novelty, Section: Political Sciences and European Studies, III(1), 13-33. Doi: http://dx.doi.org/10.18662/lumenpses.2015.0301.02 
The Republic of Moldova and Ukraine in the Context of Russian Federation's (...) Svetlana CEBOTARI, Carolina BUDURINA-GOREACII

countries with the European Union and completion of negotiations on the Association Agreement, including the Agreement on the Deep and Comprehensive Free Trade Area.

Analysing the Russian Federation strategies for maintaining in the sphere of influence of Moldova, beside the hard power strategy, that includes the use of military and economic tools, now, Russia uses also the strategy of the soft power. The concept of soft is opposite of the hard, which is a coercive, military and economic force. In a narrow meaning, the soft power, in the opinion of J. Nay is the ability of a state to get what he wants from another state. Thus, a state through soft power develops without using military defence capacity (Stan, 2015). The Russian Federation soft power focuses on a combination of tools including nationalist ideology, manipulation with symbols and nostalgia for the past, an economically and politically attractive genre for emigrants from the ex-Soviet republics.

As one of the main sources of information for most people in the CIS countries, the Russian press is used as one of the tools with which the Kremlin is promoting its policy in the region. A proof in this case refers to Moldova where during the last eight years there have been seen several changes of Russian mass-media attitude that took place simultaneously with the change of the Russian official discourse in relation to Moldova. Besides the traditional propaganda tools through news, analytical programs and talk shows, there are used also indirect instruments such as movies, concerts, sports and other non-political programs, but which are extremely popular outside the borders of Russian Federation and often they are more effective than those of a clearly political dimension. There are many Russian channels, including - Pervii Kanal, RTR, RTR Planeta, Rossiya 1, Rossiya 2, Rossiya 24, Peatyi Canal, Canal 3, Sarafan, Kinoliux, Ren, Nostalgia, STS, SET, TNT Bravo, TV 1000, TV 1000 Action, TV 1000 Russcoe Kino, Detskoe kino, TV Tentr, Karusel, MIR, MUZ TV, Nashe Kino, Domasnii, Iliuzion +, Draiv, and ribolov Ohotnik, Mnogo TV, Domasnie jivotnie, RBK TV, 24 Techno, Usadiba, NTV+ Nase Novoie kino, NTV + Sport, NTV + Kino Klub, Russkiy ekstrim, Avto Plius, India, Boets, Mati i ditea, Kuhnea, Komedia, Detskii Klub, Detskii, Retro, Dom Kino, Russkaia noci, etc. Moreover, Euronews, History, Animal Planet, National Geographic and others of general culture are in Russian language. That is while consumers of programs have only the access to TVR mixt and Pro TV of Romanian televisions. It is impossible to watch a football match, public debate, but first of all news, reports about handcuffing and conviction of criminals on

Cebotari, S., Budurina-Goreacii, C. (2015). The Republic of Moldova and Ukraine in the Context of Russian Federation's Sphere of Influence. Logos Universality Mentality Education Novelty, Section: Political Sciences and European Studies, III(1), 13-33. Doi: http://dx.doi.org/10.18662/lumenpses.2015.0301.02 
Romanian televisions. That happens at Sun TV, the largest distributor of services in Chisinau. Of Ukrainian channels, there is only one TV stationInter (Nastase, 2015).

This influence of Russian media (primarily the television) has made over the years, in Moldovan mind to become Russia one of the immediate neighbours of Moldova, excluding natural neighbour - Ukraine, although the geographical distance up to Russian border is more than $500 \mathrm{~km}$. Also due to this influence, Moldovans know better the situation in Russia than even in Moldova, and for many of them, informative TV News "Vremea" on Pervii Canal, which is issued in Chisinau at $8 \mathrm{pm}$ (local time), is the window of understanding and watching what happens in the world, and "Messenger" on public television, which is issued at $9 \mathrm{pm}$, is a kind of local TV News which informs about the life of the country.

Moscow launched an unprecedented propagandistic campaign during the Cold War focused against the West by expanding the role of "TV News" of Kremlin, RT, and through launching a radio service and news websites, Sputnik, which is issued not only in CIS countries, but also throughout the world. Priority targets are former Soviet Union and former communist European states (***, 2015, Timpul.md).

Today Moldova is the target of several hybrid forms of attack from Russian structures. Most importantly refers to the attack targeting the southern territory, given to the Gagauz minority in 1994 and forcing international law to develop its language and culture. Kremlin took over the strategic initiative and uses the autonomy as part of the hybrid war in this region of Southeast Europe. Moscow emissaries come to Comrat as in a province of Russia and are not reluctant to attack Moldova through various statements (Saharneanu, 2015). There were many Kremlin attempts in the past two years to create a pro-Russian coalition in Moldova. Moscow hoped that Moldova would have modest results in the European integration process. All this had to bring according to Kremlin, the communists to power (Calugareanu, 2012).

Russian Orthodox Church is considered to be one of effective instruments for propagation of Russian interests in areas which Moscow considers areas of influence. Moldova is part of this group of countries, because the majority of the population is Christian-Orthodox and the Church institution itself is one with the highest degree of trust by Moldovans. Although in Moldova officially the Church is separated from the state, it plays an important role in everyday life. Usually the priests are

Cebotari, S., Budurina-Goreacii, C. (2015). The Republic of Moldova and Ukraine in the Context of Russian Federation's Sphere of Influence. Logos Universality Mentality Education Novelty, Section: Political Sciences and European Studies, III(1), 13-33. Doi: http://dx.doi.org/10.18662/lumenpses.2015.0301.02 
influential in villages where their opinions are taken into account. Using the Church for political purposes has been and continues to be a thing often used by politicians in Chisinau. This fact was acknowledged by the Communist Party, which though came to leadership in 2001, on their platform religious values were not included and Communist leader V. Voronin said that is an atheist (according to the documents submitted to the Central Election Commission). Shortly Communist Party began to pay a special attention to the Church. In this context under the patronage of the President V. Voronin during his mandate there were restored several churches and monasteries, including some monuments such as the Monastery Capriana and Curchi, actions that have attracted sympathy from the public, especially from those of the third age, which is actually the main electorate of this party. Meanwhile, Communist Party pays also special attention to celebrating religious holidays. And in the dispute between the Moldovan Church, which is subordinated to the Moscow Patriarchate and the Bessarabian Church, subordinated to the Romanian Patriarchate, it is supported the first one, long time not recognizing Bessarabian Church, even if under the Moldova legislation it is stipulated that each person has the right to choose the desired religious cult, having to do only after the European Court of Human Rights ordered the Republic of Moldova to legalize its status. In response to this attention from the state, Moldovan Church, which is subordinated to the Moscow Patriarchate, also supports the Communist Party, where there are cases when during election campaigns, the priests have made propaganda encouraging people to vote for the party, and as experts mentioned in elections, this has an important impact, where the Moldovan society, especially rural ones often believe in what spiritual leaders say (***, 2009, Asociatia pentru Politica Externa).

Citizen's protection living outside the borders is one of the pretexts often used by the great powers when trying to expand their influence over other countries. The same practice is also used by Russian Federation in relation to other ex-Soviet countries, including Moldova. Each time when the relationship with Russia worsens there appear in the Russian press talks about the situation of Russian community in Moldova, which is rather precarious. However, the situation of the Russian minorities in Moldova is a special one in relation to Baltic countries which Moldova is often compared to this chapter. In the opinion of many experts who deal with the problem of national minorities the Moldovan legislation is one of the best that exists in this region. When adopting the "Law on National Minorities" this

Cebotari, S., Budurina-Goreacii, C. (2015). The Republic of Moldova and Ukraine in the Context of Russian Federation's Sphere of Influence. Logos Universality Mentality Education Novelty, Section: Political Sciences and European Studies, III(1), 13-33. Doi: http://dx.doi.org/10.18662/lumenpses.2015.0301.02 
document was praised even by V. Klimenko, the leader of the Congress of Russian Communities of Moldova who said that "the power finally began to be interested in the situation of minorities". Russian minorities seem to be the most active from all national minorities in Moldova. Firstly it happens because of the "ethnic movement" status and the influence that Russian language has in the region. Both officially and unofficially, Russian language is used at the same level as the state language, and in some sectors is even practically dominant. According to Moldovan law, all official documents are issued in both languages, civil servants are obliged to know them and respond to citizens' demands in the language in which it was requested in the application. In Moldova's Government and the Parliament there are officials, even ministers and deputies who speak only Russian. Therefore, many of the high-level meetings such as meetings of the Government or the Presidency, discussions are held in Russian language and the Parliament's plenary sessions are translated simultaneously for deputies who do not speak the state language. Currently, according to the last census from 2004 there were 201212 Russians in Moldova which represents approximately 5.9\% of the entire population of the country, most of them, more than two thirds living in urban areas. Moreover, it is interesting the fact that, for some of the other nationalities, Russian language is considered the native one, which makes de facto Russian-speaking population to be something more. The most Russian speakers live in cities, of which almost half of them are concentrated in Chisinau. Also, a large number of citizens are concentrated in the second biggest city - Balti and in many other northern districts of Moldova. Also in Moldova a large number of ethnic Russian organizations activates, which are funded by central or local authorities from Russia. Among the biggest ones we can mention the Russian community in Moldova and the Congress of Russian Communities. Although now ethnic Russians organizations are not as active as other organizations in Ukraine or the Baltic countries, they seem to be some pressure groups which are used by Moscow when it needs to publicize certain events (***, 2009, Asociatia pentru Politica Externa).

The war in Ukraine revived the issue of Russia's position in the international arena, using in addition to the hard power new tools of the soft power, such as electronic warfare, intimidation, bribery, propaganda through the internet / media, aiming to undermine the Ukrainian resistance and to avoid the use of military power (***, 2009, Asociatia pentru Politica Externa). The result was a clear military victory, by using a well oriented

Cebotari, S., Budurina-Goreacii, C. (2015). The Republic of Moldova and Ukraine in the Context of Russian Federation's Sphere of Influence. Logos Universality Mentality Education Novelty, Section: Political Sciences and European Studies, III(1), 13-33. Doi: http://dx.doi.org/10.18662/lumenpses.2015.0301.02 
strategic communication campaign, using tools of political, psychological and information domain - what is called by military thinkers "the war of the new generation". To avoid the inducing false impression that we discuss about a new generation of wars, which was inaugurated by Russia during the Crimean actions, we emphasize that military actions under this category, belong actually to the category known as "the war of the 4th generation". So Russia's vision of modern warfare is based on the idea that the human mind is the main tool of war. As a result, the war of the new generation will be dominated by the confrontations in the informational and psychological domain. Superiority on troops and weapon systems of opponent will be achieved through their mind and spirit of the armed forces and its civilian population, its main objective aiming at minimizing the need to deploy military power (hard power) and determining the soldiers and enemy's civilian population to support the actions of the attacker, to the detriment of their own governments and countries. In this context, it is interesting to note the term of "permanent war", as it means a "permanent enemy". In the current geopolitical structure, the clear opponent of the Russian Federation refers to Western civilization - values, culture, political system and Western ideology (Analiza CESI ,p.132).

For the specific case of Crimea, Russians have placed the influencing idea in the centre of operational planning. To put into practice this idea, there have been used all the tools they had: ingenious methods of internal communication, deception operations, psychological operations, well-built external communication. Deception operations were performed in Russian Federation, as military exercises, including the Kaliningrad region, to increase the insecurity of Baltic states, former Soviet republics and Poland. In the strategic communication plan, the Ukrainian media has become inaccessible and Russian channels have promoted Kremlin's version, building a parallel reality that, in the public perception, has legitimized Russia's actions.

There were three target audiences of crucial importance: the Russianspeaking majority population of Crimea, Ukrainian governmental leadership and the international community - specifically NATO and the EU. Armed with these tools Russian Federation has proved that the old Soviet art on reflexive control is present in Kremlin. By expression of reflexive control we want to be understood the control over the opponent by influencing the relationship it has with itself: its determination to take decisions

Cebotari, S., Budurina-Goreacii, C. (2015). The Republic of Moldova and Ukraine in the Context of Russian Federation's Sphere of Influence. Logos Universality Mentality Education Novelty, Section: Political Sciences and European Studies, III(1), 13-33. Doi: http://dx.doi.org/10.18662/lumenpses.2015.0301.02 
predetermined and desired by the initiator of the action (Analiza CESI, p.133).

To this end, since 2003-2004, Kremlin have been seeking new tools of action, aimed to influence, to get ideas and adherence to its tenets: restructuring RIA Novosti, the main Russian information agency, modernization of external broadcasting by creating a network of programs such as Russia Today (RT) with an emission of 24 / 24 hours (it has been issued in English language since 2005, Arabic-2007, Spanish-2009), it is created the Valdai Discussion Club, NGOs and foundations that have the task to strengthen Russia's presence at the international level. Also an important role refers to RuNet - Russian Internet. In order to strengthen its presence in innovation field, it initiates a policy of branding the Skolkovo project (Sieg, 2014).

To achieve its goals in foreign policy, Russia must improve its perception at the international level. V. Putin uses a new tactic in his play smart power, which is used in states in the close proximity. Thus, there are used TV channels issued in Russian-language that are broadcasted abroad and are much more famous than local ones (***, 2015, Timpul.md).

\section{Conclusion}

Developing the soft power, Russia faces a number of problems (Tinguy, 2015). The partnerships in cultural and scientific domain are another aspect of humanitarian direction and primarily aim at halting the processes of modifying the history in the post-Soviet history. Thus, there are created centres that belong to Ruskii Mir Foundation and in the concerned countries it is brought Russian literature, history books and other materials designed to not allow another interpretation. Mass media is also one of the main sources of information for most people in the CIS countries. Russian media is used as one of the tools with which Kremlin promotes its policy in the region.

The analysis of Russian's Federation hard and soft power, as strategies of hybrid war, brings into question the use of Moscow's tools on Chisinau and Kiev which includes both the use of force by maintaining separatism in eastern Moldova and Ukraine, the use of economic tools such as energy blackmail; embargoes on local and Ukrainian products, in particular on agricultural products and wine, on fruit and vegetables and the protection of the interests of ethnic Russians through means of communication, seem to

Cebotari, S., Budurina-Goreacii, C. (2015). The Republic of Moldova and Ukraine in the Context of Russian Federation's Sphere of Influence. Logos Universality Mentality Education Novelty, Section: Political Sciences and European Studies, III(1), 13-33. Doi: http://dx.doi.org/10.18662/lumenpses.2015.0301.02 
The Republic of Moldova and Ukraine in the Context of Russian Federation's (...) Svetlana CEBOTARI, Carolina BUDURINA-GOREACII

be more (geo) political and (geo) strategic strategies with the decision of Chisinau and Kiev to move closer to the EU.

\section{REFERENCES}

*** (2015). Analiza CESI: Rusia pregătește războiul hibrid pe frontul Moldovei. Comandantul fortelor NATO vrea cadrul legal pentru protejarea aliaților non-membri. Ne apropie acest lucru de un război nuclear? [CESI Analysis: Russia is preparing a Hybrid War in Moldova. NATO Forces want Legal Framework to protect its NonMember Allies. Does this Fact approach us to a Nuclear War?] In Evenimentul Zilei Moldova.

http://www.evzmd.md/presa-externa/351-presainternationala/16043-un-razboi-hibrid-in-imediata-vecinatatedespre-vulnerabilitatile-republicii-moldova.html (Accessed on: 20.04.2015)

*** (2015). Propaganda, arma Rusiei în războiul hibrid împotriva Occidentului şi a României, [Propaganda, Russia's Weapon in the Hybrid War against the West and Romania]. In Timpul.md. Available online at:

http://www.timpul.md/articol/propaganda-arma-rusiei-in-razboiulhibrid-impotriva-occidentului-i-a-romaniei-70059.html (Accesed on: 22.04.2015).

*** (2009). Scurt istoric al evoluției relaţiilor Republicii Moldova cu Rusia, [Brief History of the Development of Relations between Moldova and Russia]. In Asociatia pentru Politica Externa. Available online at: http:/ / www.ape.md/libview.php?l=ro\&idc=152\&id=855 (Accessed on: 22.04.2015).

*** (2008). Embargoul rus asupra vinurilor din Republica Moldova şi Georgia (2006) [Russian Embargo on Moldova and Georgia wine (2006)]. Available online at: http://www.culiuc.com/archives/2008/03/agriculture4.phtml (Accesed on: 22.12.2014).

***, Europa Războiul hibrid al lui Putin amenință Moldova, avertizează Pentagonul şi NATO, [The Europe's Hybrid War of Putin threatens Moldova's, warns Pentagon and NATO]. In Adevarul.ro. Available online at: http://adevarul.ro/international/europa/razboiul-hibridputin-ameninta-moldova-avertizeaza-pentagonul-nato1 54ef49d5448e03c0fd03da (Accesed on: 22.04.2015).

Cebotari, S., Budurina-Goreacii, C. (2015). The Republic of Moldova and Ukraine in the Context of Russian Federation's Sphere of Influence. Logos Universality Mentality Education Novelty, Section: Political Sciences and European Studies, III(1), 13-33. Doi: http://dx.doi.org/10.18662/lumenpses.2015.0301.02 
Baltag, A. (2010). Arma energetică a Rusiei ca instrument de presiune şi de influenţă în spaţiul ex-sovietic (cazul Republicii Moldova şi al Ucrainei). [Russian Energy Weapon as an Instrument of Pressure and Influence in Ex-Soviet Area (Case Republic of Moldova and Ukraine). Foreign Policy Association]. In Asociația pentru Politică Externă. Available online at: // http://www.ape.md/doc.php?l=ro\&idc=156\&id=1139 (Accessed on: 02.02.2015).

Calugareanu, V. (2012). Plan dur de menținere a Moldovei în sfera de influență a Rusiei. [Though Plan of maintaining Moldova under the Russia's Sphere of Influence]. Available online at: http://www.dw.de/plan-dur-de-men $\% \mathrm{C} 5 \%$ A3inere-a-moldovei\%C3\%AEn-sfera-de-influen $\%$ C5\%A3\%C4\%83-a-rusiei/a-15840473 (Accessed on: 22.04.2015).

Gribincea, M. (1999). Politica rusă a bazelor militare. Moldova şi Georgia . (Russian Policy of Military Troops. Moldova and Georgia). Chişinău: Ed. „Civitas”.

Goncearov, V. (2009). Embargo comercial extins al Rusiei asupra unor produse lactate din Belarus [Russian extended Trade Embargo on some Dairy Products from Belarus]. In Radio Europa Libera. Available online at:

http://www.europalibera.org/archive/news/20090610/445/445.ht ml?id=1750739 (Accessed on: 02.02.2015

Nastase, V. (2015). Statul lui Timofti sau Ghetoul spălărilor de creier, [Timofti's State or the Ghetto of Brain Laundering]. In Independent.md. Available online at: http://independent.md/statul-luitimofti-sau-ghetoul-spalarilor-de-creier/\#.VO9R4I7 HIU

Saharneanu, V. (2015). Războiul hibrid al Rusiei, de unde vine şi cum a ajuns in Republica Moldova, [Russia's Hybrid War, where it is from and how it came to Moldova]. Available online at: http://valeriusaharneanu.com/?p=1050(Accesed on: 22.04.2015).

Sieg, M. (2014). Care sunt interesele Uniunii Europene în Moldova?. In IPN.ro. Available online at: http://www.ipn.md/ro/integrareeuropeana/63899 (Accessed on: 22.04.2015).

Stan, L. G. (2015). Comandantul NATO în Europa: Rep. Moldova, în plină ofensivă propagandistică a Rusiei, [NATO Forces in Europe: Moldova, under Propagandistic Campaign of Russia]. In InfoPrut.ro. Available online at: http://infoprut.ro/36865-comandantul-natoeuropa-rep-moldova-plina-ofensiva-propagandistica-rusiei.html (Accessed on: 22.04.2015).

Cebotari, S., Budurina-Goreacii, C. (2015). The Republic of Moldova and Ukraine in the Context of Russian Federation's Sphere of Influence. Logos Universality Mentality Education Novelty, Section: Political Sciences and European Studies, III(1), 13-33. Doi: http://dx.doi.org/10.18662/lumenpses.2015.0301.02 
Tinguy, A. (2015). Russie: le syndrome de la puissance. In Ceriscope.fr. Available online at: http://ceriscope.sciencespo.fr/puissance/content/part4/russie-le-syndrome-de-lapuissance?page $=3$ (Accessed on: 22.12.2014).

Cebotari, S., Budurina-Goreacii, C. (2015). The Republic of Moldova and Ukraine in the Context of Russian Federation's Sphere of Influence. Logos Universality Mentality Education Novelty, Section: Political Sciences and European Studies, III(1), 13-33. Doi: http://dx.doi.org/10.18662/lumenpses.2015.0301.02 